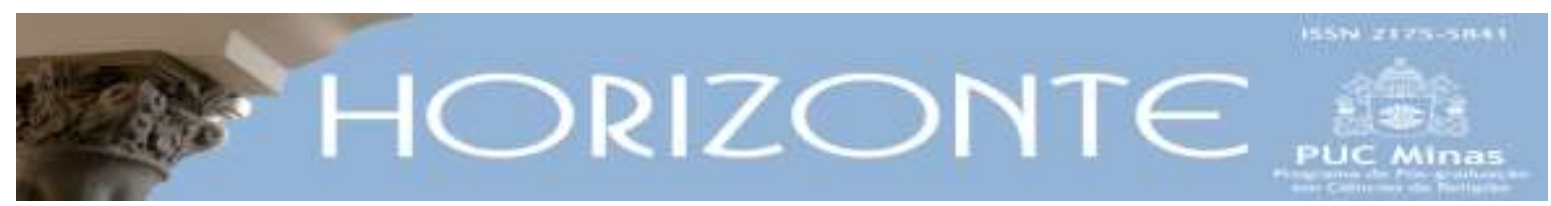

Temática Livre - Artigo Original

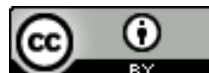

DOI - 10.5752/P.2175-5841.2016v14n44p1398

\title{
Por uma catequese mais pneumatológica: o terceiro paradigma catequético formulado por Denis Villepelet
}

\author{
For a more pneumatological catechesis: the third catechetical paradigm \\ formulated by Denis Villepelet
}

Solange Maria Carmo*

\section{Resumo}

Vivemos tempos de redescoberta da ação do Espírito, exigindo da catequese novos contornos, especialmente no que diz respeito à teologia que ela transmite e à pedagogia que a caracteriza. O catequeta francês, Denis Villepelet, propõe um terceiro paradigma catequético, nascido das exigências próprias do tempo presente, mais comumente chamado de pós-modernidade. Sua catequese pneumatoderivada se distingue bem da catequese teoderivada do primeiro paradigma - formulado a partir do modelo da cristandade e reafirmado em Trento - e da catequese cristoderivada do segundo paradigma - formulado a partir de princípios da modernidade e reafirmado no Vaticano II. Para compor o terceiro paradigma, Villepelet pensa as bases sociológicas, antropológicas, eclesiológicas, teológicas e pedagógicas da catequese. Mas uma catequese mais pneumatológica, por não estar ainda bem definida e trazer algumas novidades que obrigam a romper com paradigmas anteriores, pode causar estranhezas, levantando suspeitas sobre sua pertinência teológico-pastoral. Por isso, torna-se fundamental avaliar os ganhos e os riscos que esse paradigma pode trazer para o ato catequético.

Palavras-chave: catequese pneumatológica, paradigma, pós-modernidade, iniciação.

\begin{abstract}
We have been living now in times of rediscovery of the action of the Spirit, demanding from catechesis new contours, especially with regard to the theology it transmits and the pedagogy that characterizes it. The French catechist, Denis Villepelet, proposes a third catechetical paradigm, emerging from the demands of the present time, more commonly called postmodernity. His pneumatoderivative catechesis differs very clearly from the teoderivative catechesis of the first paradigm - formulated from the model of Christianity and reaffirmed in Trent - and from the Christocentric catechesis of the second paradigm - formulated from the principles of modernity and reaffirmed in Vatican II. To compose the third paradigm, Villepelet thinks about the sociological, anthropological, ecclesiological, theological and pedagogical foundations of catechesis. However, a more pneumatological catechesis, because it is not yet well defined and because it brings some novelties that compel to break with previous paradigms, can cause strangeness, raising suspicions about its theological-pastoral pertinence. Therefore, it is fundamental to evaluate the gains and risks that this paradigm can bring to the catechetical act.
\end{abstract}

Keywords: pneumatological catechesis, paradigm, postmodernity, initiation.

\section{Resumé}

Nous vivons maintenant dans des temps de redécouverte de l'action de l'Esprit, exigeant de la catéchèse de nouveaux contours, surtout en ce qui concerne la théologie qu'elle transmet et la pédagogie qui la caractérise. Le catéchiste français, Denis Villepelet, propose un troisième paradigme catéchétique, émergeant des exigences actuelles, plus communément appelées postmodernité. Sa catéchèse pneumatoderivante diffère très nettement de la catéchèse teoderivative du premier paradigme - formulé à partir du modèle du christianisme et réaffirmé à Trente et de la catéchèse christocentrique du second paradigme - formulée à partir des principes de la modernité et réaffirmée dans Vatican II. Pour composer le troisième paradigme, Villepelet pense aux fondements sociologiques, anthropologiques, ecclésiologiques, théologiques et pédagogiques de la catéchèse. Mais une catéchèse plus pneumatologique, car elle n'est pas encore bien définie et parce qu'elle apporte quelques nouveautés qui obligent à rompre avec les précédents paradigmes, peut provoquer l'étrangeté, suscitant des soupçons sur sa pertinence théologique-pastorale. II est donc fondamental d'évaluer les gains et les risques que ce paradigme peut apporter à l'acte catéchétique.

Mots-chés: catéhèse peneumatologique. Paradigme. Posmodernité. Initiation.

Artigo submetido em 03 de junho de 2016 e aprovado em 22 de outubro de 2016.

* Doutora e Mestre em Teologia (FAJE), professora da PUC-Minas e do ISTA. País de Origem: Brasil. E-mail: carmosolange@gmail.com

Horizonte, Belo Horizonte, v. 14, n. 44, p. 1398-1421, out./dez. 2016 - ISSN 2175-5841 


\section{Introdução}

Depois de tempos relegado a segundo plano na prática da piedade católica, o Espírito Santo veio a descoberto. A Terceira Pessoa da Santíssima Trindade entendida popularmente, por uns, como força ou luz ou, por outros, como uma pomba do céu - ganhou espaço na vida dos cristãos, especialmente dos católicos. Uma reviravolta se deu ${ }^{1}$. O Deus desconhecido ${ }^{2}$ mostrou seu rosto. Em toda reunião, em toda celebração, o povo de fé canta hinos ao Espírito, invoca sua força e pede sua sabedoria. A canção que ressoava nas comunidades eclesiais de base "Vem, entra na roda com a gente" perdeu a preferência no gosto popular e agora nossa gente canta "Espírito, Espírito, que desce como um fogo, vem como em Pentecostes e enche-me de novo".

Também na catequese, observamos mudanças. A catequese cuja atenção estava focada nos mistérios da criação e da encarnação, volta-se para o mistério pascal que mostra sua plenitude na efusão do Espírito Santo sobre os discípulos em Pentecostes. Pelo poder do Espírito, os discípulos de Jesus renovam suas forças no Caminho e unem suas vidas à dele glorificando o Pai. A catequese, compreendendo a necessidade do discipulado de Jesus, tenta corrigir um déficit de iniciação deixado pelas catequeses anteriores e conta com a força renovadora do Espírito nesse empreendimento. Já vemos florescer nas paróquias uma catequese bem mais pneumatológica que as anteriores.

Neste artigo, faremos conhecer o terceiro paradigma catequético, formulado pelo catequeta francês, Denis Villepelet3; uma catequese notadamente pneumatológica. Não se trata de um paradigma já construído, alicerçado e presente

\footnotetext{
${ }^{1}$ Em 2011, González-Faus escreveu sobre a urgência de uma revolução pneumatológica, tarefa que se espera da teologia no futuro (2011, p. 264).

${ }^{2}$ Segundo Codina, no Ocidente, prevaleceu o cristocentrismo da fé, por vezes podendo ser dito como cristomonismo (2012, p. 69-86).

${ }^{3}$ Para conhecer melhor o pensamento do catequetas francês recomendamos CARMO, Solange Maria. Catequese no mundo atual: crises desafios e um novo paradigma catequético. São Paulo: Paulus, 2016. Ou a única obra do autor traduzida para o português: 0 futuro da Catequese. São Paulo: Paulinas, 2003.
} 
nas paróquias, mas de um paradigma em vias de construção, cujos sinais já se mostram nas práticas eclesiais evangelizadoras4.

\section{Conhecendo o paradigma}

A teologia catequética de Denis Villepelet propõe compreender a catequese a partir de três paradigmas distintos: o paradigma da cristandade, o paradigma da modernidade e o paradigma da pós-modernidade5. Para cada um desses paradigmas, cinco campos do conhecimento interagem entre si com seus parâmetros dominantes. São o campo sociológico, o campo antropológico, o campo teológico, o campo eclesial e o campo pedagógico.

Neste artigo, trataremos apenas do paradigma da pós-modernidade, o terceiro paradigma, cuja catequese adquire contornos pneumatológicos. Conheçamos os parâmetros dominantes que o compõem. Antes, porém, uma observação. Vou me permitir escrever tudo na primeira pessoa do plural, para deixar claro o lugar do qual falo: "desde dentro" da pós-modernidade, dando voz a nossos irmãos e irmãs contemporâneos, sem o olhar saudosista do passado, seja da cristandade, seja da modernidade.

\section{a) Sociedade complexa}

Para eficácia da catequese cristã, é um imperativo a sua encarnação no chão da história, afinal um dos mistérios celebrados pela fé cristã é a encarnação do Verbo Divino: Deus se fez homem e habitou entre nós (cf. Jo 1,14). Em tempos de pós-modernidade, fazer catequese como no passado seria imprudência; a sociedade

\footnotetext{
${ }^{4} \mathrm{O}$ grande mérito de Denis Villepelet foi tematizar os paradigmas catequéticos, categorizá-los, explicitá-los, distingui-los. Certamente, ele não inaugura um novo paradigma, pois o terceiro paradigma identificado por ele como próprio para a pós-modernidade tem raízes antigas na história da Igreja, no catecumenato cristão. A pedagogia da iniciação do terceiro paradigma foi, nos quatro primeiros séculos da Era Cristã, o caminho catequético próprio da Igreja, e a atenção ao Espírito sempre foi uma marca na Igreja nascente. O catequeta francês, no entanto, atento aos sinais dos tempos, identificou a necessidade da passagem do segundo paradigma - antropológico, moldado conforme critérios da modernidade - para um paradigma conforme exigências da pós-modernidade.

${ }^{5}$ Não vamos discutir aqui a escolha do termo pós-modernodade, tão polêmico, intitulado por outrs estudiosos de modernidade líquida, hipermodernidade etc. Vamos nos ater à escolha do autor, por fidelidade à sua teologia.
} 
contemporânea tem outra configuração que não as das sociedades de outrora. Uma sociedade complexa, diversificada, plural - bem diferente da sociedade tradicional da cristandade ou da sociedade evolutiva da modernidade nas quais já estávamos acostumados a fazer catequese - se nos apresenta pedindo para ter sua gramática decifrada.

Ao olharmos para o mundo atual, percebemos que a sociedade não se rege pela tradição transmitida por nossos antepassados como nos tempos da cristandade, nem pelo ritmo cadenciado da razão como na sociedade moderna. A sociedade se apresenta hoje muito mais flexível e diversificada, marcada pelo novo que irrompe a cada instante. A previsibilidade - ditada pela tradição (cristandade) ou pelas projeções da razão humana (modernidade) - partiu-se como um cristal no frenesi das novidades aceleradas da pós-modernidade. Sobraram cacos de evidência que não nos permitem projetar o futuro, nem fazer previsões certeiras. Uma sociedade complexa ganhou corpo. Formou-se uma teia de relações, tecida por múltiplos fios que se entrelaçam e se sustentam uns aos outros. São diversas culturas, diversos grupos, diversos valores, diversas referências... Não há mais uma grande narrativa ou uma grande disciplina (apesar da tentativa de retorno a isso, por meio de grupos neoconservadores), que possa explicar a vida ou responder aos nossos anseios. Vivemos hoje numa sociedade composta por múltiplas sociedades intercomunicantes, cada qual com sua lógica própria. A lei que dita as relações é a interdependência, e a independência - que antes significava autonomia e autossuficiência - hoje é decreto de morte. Nenhuma cultura sobrevive mais sem efetuar trocas com as demais. Nenhuma delas pode mais ser reproduzida em autarquia; nenhuma tem a palavra definitiva. Surgem múltiplas possibilidades combinatórias. Todos os gostos, todos os valores passam a coabitar juntos sem se excluir. Nesse entrelaçamento, a sociedade contemporânea ganhou uma configuração de estado crítico permanente ${ }^{6}$. Uma crise que não significa caos, nem ${ }^{6} \mathrm{O}$ estado de crise não tem conotação negativa, apenas significa uma sucessão contínua de mudanças. Confira CARMO, Catequese no
mundo atual, p. 105-118 
revela necessariamente necessidade de ser superada. Ou ainda, um caos organizado onde nós nos encontramos, apesar de sua aparente falta de lógica.

\section{b) Indivíduo sujeito}

Nessa sociedade em estado de crise, sem referências estáveis, percebemonos cada vez mais livres para ser o que quisermos. Mais livres, mas também infinitamente mais desamparados. Sentimo-nos perdidos, sem um mapa para nos orientar. Muitas escolhas de vida que, em outros tempos, nos eram dadas pelo meio social e cultural hoje devem ser elaboradas. Cada um de nós se vê impelido, obrigado a ser autor de suas próprias escolhas, tanto morais como existenciais. Estamos sozinhos para achar nossas próprias referências (LACROIX; VILLEPELET, 2008, p. 23). Como afirmou Villepelet, nos movemos no terreno da “incerteza identitária” (2001, p. 36). O barco de nossa vida zarpa rumo ao porto da realização, mas falta-lhe o farol da memória histórica, apagado pela ruptura da crise da transmissão. Perdidos nesse mar - tantas vezes revolto - buscamos luzes interiores, referências ou balizas dentro de nós mesmos, capazes de nos mostrar o ponto de chegada. Assim, a busca da própria identidade se impõe autoritária, sendo sacudida às vezes pelo vento do individualismo ou por tempestades narcísicas. Mas a explosão individualista contemporânea, longe de ser mero capricho de nós, pósmodernos, "indica uma formidável necessidade de identificação e de enraizamento" (VILLEPELET, 2008a, p. 387), sem a qual viveremos à deriva ou naufragaremos. Tomados pela liberdade, somos obrigados a nos encontrar, a nos tornar atores de nossa própria existência. Como escreveu Villepelet, ser sujeito de nossa própria vida não se apresenta como uma opção, mas como um imperativo; a liberdade tornou-se nossa maior obrigação (2000). Não há para onde fugir dessa imposição. Ou nos empenhamos no laborioso trabalho da edificação de nossa interioridade ou seremos consumidos pelo fogo devorador de uma existência sem sentido. Restanos montar o quebra-cabeça de nossa vida com as peças que catamos depois do vendaval da história. O problema é que não existem manuais confiáveis, capazes de 
nos indicar por onde começar o trabalho. Sentimo-nos atordoados sem saber por onde começar.

\section{c) Teologia paneumatoderivada}

Mudou a sociedade. Mudamos nós. Muda-se a teologia catequética.

A catequese, a quem antes foi atribuída a função de burilar a fé, vê-se desafiada a comunicar a experiência cristã de Deus, capaz de se tornar elemento integrador da vida humana. O encontro com Jesus Cristo, morto por causa de sua fidelidade ao projeto do reino mas ressuscitado pelo Pai e vivo entre nós pela ação de seu Espírito, tornou-se o grande objetivo da catequese, pois nós, pós-modernos, não somos mais marcados por experiências cristãs como outrora. Proclamar, celebrar e viver o mistério pascal pela ação do Espírito: eis o desafio da catequese cristã hoje. Esse mistério é o centro da fé cristã; não um detalhe ou um anexo em meio a doutrinas, dogmas, normas éticas e práticas religiosas. Tendo centralidade na fé cristã, adquire também centralidade na catequese da Igreja.

Sabemos, porém, que um mistério não é algo construído como um saber. Não desvelamos o mistério cristão por força do raciocínio, pois ele não é um enigma a ser desvendado nem um código secreto a ser decifrado. Acolhemo-lo como puro dom, como imensidão de amor que nos transcende e pede reverência. Pela fé, somos mergulhados no mistério; somos nele iniciado. Conforme Villepelet, essa iniciação pode se efetuar pedagogicamente de três maneiras (VILLEPELET, 2009b, p. 336).

Uma primeira possibilidade de fazer o mergulho no mistério divino é começar pela experiência do Pai. O iniciado experimenta a força paterna de Deus que, na história, diz sua palavra na pessoa do Verbo Encarnado e mostra sua força pela ação do Espírito. Vai-se do Pai ao Filho, na comunhão do Espírito Santo. É o caminho da teologia teocentrada ou teoderivada. Sobre essa teologia, Villepelet fala amplamente quando formula o primeiro paradigma. 
Uma segunda possibilidade de mergulho tem seu início no Filho. O iniciado é confrontado com Jesus de Nazaré e o movimento em seu entorno: o evento Cristo. O Filho nos mostra na sua vida cotidiana quem é o Pai, pois suas palavras e obras são ação do Espírito. Agindo sob a força do Espírito, ele revela o rosto misericordioso de Deus Pai. Essa catequese nos leva do Filho ao Pai, pela ação do Espírito. É o caminho da teologia cristocentrada ou cristoderivada, pois seu ponto de partida é a humanidade de Cristo. Tal teologia, Villepelet aprofunda quando trata do segundo paradigma.

Uma terceira possibilidade de abertura ao mistério tem seu começo na ação do Espírito. Tocados pela ação do Espírito do Ressuscitado, conhecemos Jesus e nos tornamos seus discípulos; por ele, somos mergulhados no amor do Pai e passamos a viver como irmãos, pois fomos irmanados no mesmo amor regenerador. Na ação do Espírito, a realidade humana encarnada por Jesus de Nazaré continua sendo tocada pela graça do Pai em cada um que acolhe seu reino, que se deixa encantar por sua proposta. Essa catequese "leva, no Espírito, do Cristo ao Pai” (VILLEPELET, 2009b, p. 337). É a teologia pneumatocentrada (VILLEPELET, 2009b, p. 337) ou pneumatoderivada (VILLEPELET, 2003, p. 95). Nela, o conteúdo da fé não é uma doutrina (como no primeiro paradigma), nem uma mensagem (como no segundo paradigma). É a mediação da abertura ao mistério; o meio que possibilita a acolhida da revelação de Deus. A proximidade de Deus acontece quando nos reunimos em seu nome e seu Espírito age desde dentro no coração humano. Nessa catequese, o encontro com Jesus Cristo se dá por meio do testemunho da experiência cristã do catequista e dos demais participantes, por meio da Palavra proclamada e partilhada, da celebração e da prece que a comunidade eleva a Deus, dos cantos e dos gestos, da brincadeira e da dança, dos símbolos e dos ritos, do silêncio e da meditação, da vida em comunhão, do compromisso com os sofredores, do serviço humilde de uns aos outros. Deus se faz presente no seu Filho pela ação do Espírito em cada experiência humana, por mais simples que ela seja. 
Tal catequese exige uma Igreja mais marcada pela dinâmica do Espírito, com limites menos rigorosos e espaços mais abertos, sem excesso de contratos ou obrigados, de modo a favorecer a afirmação da subjetividade dos que foram congregados pelo Espírito.

\section{d) Igreja templo do Espírito}

Nos tempos da cristandade, entendíamos a Igreja como uma sociedade hierarquicamente constituída e com funções muito bem definidas. A melhor imagem bíblica para dizer essa Igreja é Corpo de Cristo. Nessa Igreja, nossa pertença era estável, pois fora herdada de nossos antepassados. Nela, eles foram batizados, cresceram na fé, receberam os sacramentos, constituíram matrimônio segundo as leis da Igreja. Nela, nos fizeram ser admitidos; nos mergulharam em seu mistério; deram-nos a fé da Igreja como herança. Nossa pertença advinha de um modo de vida que nos fora transmitido; havia um ethos cristão que a favorecia. A hierarquia da Igreja, com seus papéis bem definidos, suas normas e observâncias, não nos incomodava ou nos causava mal-estar. Ao contrário, nos dava segurança e garantia a unidade da fé.

Na modernidade, a Igreja ganhou nova configuração. Boa imagem para representa-la é a metáfora Povo de Deus: uma gente congregada pelo Senhor, que marcha rumo ao reino. O reino esperado vai sendo construído pela militância de cada companheiro de jornada, que assume seu papel de ator social. Nesse tempo, a fé católica representava para nós o núcleo de nossa identidade simbólica. Aderíamos à missão da Igreja; sonhávamos seus sonhos; seus projetos eram os nossos. Nós nos sentíamos desafiados a ser atores engajados, agentes sociotransformadores cuja atuação no mundo era vista como uma forma de apostolado. Nós acreditávamos no ideal da Igreja que marchava rumo ao reino definitivo e, para participar desse projeto e nos engajar nessa marcha, valia toda renúncia e todo sacrifício. 
Na pós-modernidade, porém, como lembra Villepelet, a imagem eclesial mais apropriada não é nem Corpo de Cristo nem Povo de Deus, mas Templo do Espírito (2009b, p. 339). Essa Igreja possibilita a íntima união com Deus; nela se experimenta a "presença viva e atual do Cristo, porque ela vive e celebra no Espírito" (VILLEPELET, 2003, p. 111). Ela “não é nem uma sociedade altamente hierarquizada, nem uma comunidade que reúne o povo de Deus; ela é uma rede interconectada, acompanhada pelo Espírito" (VILLEPELET, 2009b, p. 346).

Nessa Igreja, experimentamos a ação do Espírito, acolhemos sua presença, deixamo-nos encaminhar pela força de seu sopro. Como o Espírito sopra onde quer e age como quer (cf. Jo 3,8), essa Igreja se revela menos espacial, com limites menos demarcados. Os limites geográficos do modelo paroquial e diocesano não podem conter o movimento do Espírito que se dá nesse povo que ele reúne. Por isso, nós, católicos de hoje, somos muito mais peregrinos e romeiros que os católicos de gerações passadas. Estamos sempre aqui e ali à procura de um espaço eclesial que nos acolha e promova nossa fé, afirmando nosso processo de interiorização. Para nós pós-modernos, "não há lugar para uma pertença eclesial fixa ou para um engajamento durável na missão, mas para uma adesão personalizada e móvel” (VILLEPELET, 2009b, p. 346). Sentimo-nos Igreja em qualquer espaço, em qualquer ajuntamento, em qualquer celebração onde o Espírito de Deus age. Somos aqueles adoradores que, como afirma o Evangelho de João, adoram não neste ou naquele monte, mas em espírito e verdade (cf. Jo 4,2124). Como afirma Villepelet, "o amor divino pulveriza os limites e transgride as sabedorias demasiado humanas" (2003, p. 111-112). Para nós, todo lugar foi santificado e se tornou templo, e toda ação genuinamente humana propicia a ação de Deus. "O templo está infinitamente aberto sobre o mundo e em solidariedade com ele” (VILLEPELET, 2003, p. 112). Basta que estejamos agrupados em nome do Ressuscitado para que sua presença seja real e transformadora, pois o Espírito continua agindo no mundo (cf. Mt 18,20).

Esses ajuntamentos, normalmente, não se dão pela obrigação do preceito, 
nem precisam ter hora e lugar marcados. As pessoas buscam experimentar a presença do Senhor e não é preciso um calendário que a favoreça. São reuniões abertas, livres, sem definições litúrgicas rigorosas. O que as motiva é o desejo do encontro com Deus e não o cumprimento de prescrições previstas por manuais, calendários e ciclos pré-estabelecidos. Nelas estão presentes tanto simpatizantes, quanto reiniciantes, quanto ainda pessoas experientes na fé cristã: jovens, velhos, crianças, adultos... As afinidades pessoais são importantes no começo, mas seus limites são ultrapassados em nome do amor que o Ressuscitado ensina a cultivar. Elas servem de primeiro elemento agregador, mas - movidos pelo Espírito de Pentecostes - os agregados se acolhem e aprendem a se amar para além de toda simpatia ou antipatia inicial. As pessoas que se ajuntam não se escolhem. São ajuntadas pelo Senhor que as atraiu, as convidou, as seduziu para esse congraçamento fraterno. Nesses grupos, todos somos bem-vindos, pois o templo não tem paredes e sempre cabe mais um que foi tocado pelo Espírito. As portas estão sempre abertas para acolher aqueles que estão à procura de um espaço para ser e para se desenvolver na presença do Ressuscitado.

Nesse modelo de Igreja, a pertença é móvel. Ela não se dá por força da obrigação, nem acontece por satisfação pessoal ou prazer; é "o resultado de uma escolha que depende do campo de investimento pessoal” (VILLEPELET, 2009b, p. 329). A adesão ao grupo é "personalizada, modulada e móvel e se integra na miscelânia de suas múltiplas adesões" (VILLEPELET, 2005, p. 7). A vida eclesial tornou-se uma rede associativa que permite nutrir a vida espiritual (VILLEPELET, 2005, p. 7). A Igreja se tornou o lugar da experiência do Espírito e de partilha da mesma. Isso não quer dizer que nós, cristãos de hoje, não estejamos dispostos à pertença e ao engajamento. Estamos dispostos a investir nossas energias na comunidade de fé, nas atividades pastorais ou sociais, desde que aí encontremos uma razão que nos mova, que dê sentido a nossas vidas, que possa favorecer o desabrochar de nossa identidade. "A pertença a uma instituição, a uma comunidade ou a um grupo não é mais um negócio de convenção, de tradição ou de obrigação; é uma questão de investimento e de desenvolvimento" (VILLEPELET, 
2009b, p. 329). Nesse modelo de agrupamento, a instituição não fica abolida; ela não se define, porém, como detentora do depósito da fé e da graça. Como afirma Villepelet, para nós, cristãos da pós-modernidade, “a Igreja não parece mais ser a dona primeira e permanente da fé, mas ela continua sendo uma mediação necessária” (VILLEPELET, 2009b, p. 23).

\section{e) Pedagogia da iniciação}

Será que a iniciação pode ser considerada uma pedagogia ao lado de outras formas mais comuns, o ensinamento e a aprendizagem? Sabemos que, na sociedade atual, a iniciação foi rebaixada ao posto de formação de base das culturas rudimentares. Nossa cultura fez uma indevida associação de iniciação com "práticas iniciais rituais e religiosas, práticas misteriosas e obscuras de uma outra época” (VILLEPELET, 2000, p. 15), cuja presença só se encontrada em sociedades que julgamos não possuir grandes desenvolvimentos intelectuais.

A crise contemporânea da transmissão que as sociedades ocidentais atravessam, no entanto, obriga-nos a repensar os processos pedagógicos do ensinamento e da aprendizagem, cujos resultados já são hoje questionados (VILLEPELET, 1993, p. 29-34). Mas não é só na sociedade secular que o ensino e a aprendizagem são colocados em xeque. Na catequese, cujo modelo atual é herdeiro do ensino-aprendizagem, também nos perguntamos se essa pedagogia coopera para o conhecimento do mistério. Sendo tão intelectiva, privilegia a parte cognitiva e ignora o mistério. Apesar do reconhecimento do valor dessas pedagogias, somos obrigados a admitir que elas não favorecem a comunicação da experiência cristã, que não se dá por força da razão mas por acolhida do amor gratuito de Deus revelado em seu Filho na cruz. Somente a pedagogia da iniciação é capaz de efetuar esse mistério, pois, para ela, este é um conceito fundamental. Se a iniciação é o processo de mergulho da pessoa no mistério, parece que já é hora de a catequese resgatar a iniciação, que ficou esquecida no passado. 
O Diretório Geral para a Catequese nos convida a "anunciar os mistérios essenciais do cristianismo, promovendo a experiência trinitária da vida em Cristo como centro da vida de fé” (DGC, n. 33). Ao fazer esse convite, a Igreja situa a catequese na dinâmica da revelação e lhe incumbe a tarefa de favorecer o encontro com Deus. Assim, a iniciação desponta como método próprio da catequese, pois lida com a categoria de mistério, abrindo portas para a revelação do Deus misterioso, o Totalmente Outro que se dá a conhecer em seu filho Jesus Cristo pela força do Espírito. Se entendemos mistério como uma realidade que nos ultrapassa e não como um enigma a ser decifrado ou uma ilusão a ser desvelada por um exame crítico e reflexivo, a iniciação se apresenta como o melhor caminho para a catequese favorecer a experiência cristã.

\section{Avaliando o paradigma}

Vejamos alguns perigos e vantagens aos quais a catequese está sujeita quando se trata do terceiro paradigma.

\section{a) Sociedade complexa}

A multirreferencialidade é característica marcante da sociedade contemporânea. Nossa pastoral acostumou-se à cristandade, afeiçoou-se a ela. Era tranquilo evangelizar sustentado por uma grande narrativa, que explicava todas as coisas: desde as desventuras pessoais até o funcionamento do mundo. A explicação totalitária da cristandade nos dava segurança enquanto que a multirreferencialidade da sociedade contemporânea a arranca de nós, obrigandonos a conviver com o diferente e a rever nossos parâmetros de julgamento. A fé cristã, cujas marcas na sociedade tradicional são inegáveis, não define mais o modo de viver do contemporâneo nem dita mais as regras de organização da sociedade complexa na qual vivemos. A sociedades cujas bases se assentavam na tradição cristã ou na razão cristã entraram em extinção. Não temos mais nem as estruturas cristãs da tradição cristã, nem os indivíduos comprometidos com o projeto do 
reino, próprios da modernidade. A sociedade pós-moderna rejeita a hegemonia cristã e, agora que os valores cristãos foram colocados sob suspeita, nós cristãos estamos meio atônitos diante do mundo. Os referenciais axiológicos que serviam de baliza para orientar nossa vida foram postos em xeque e nossa vida parece de ponta-cabeça, pois encontra-se definida por gostos e valores pessoais, nem sempre tão bem definidos. É o processo de subjetivação ao qual a sociedade contemporânea obriga seus indivíduos. Então, diante disso, perguntamos: uma catequese mais pneumatológica, que descarta a hegemonia cristã da sociedade e aprova o processo de subjetivação dos valores proveniente da multirrefeencialidade que se instalou, estaria contribuindo para a extinção dos valores éticos aos quais a fé cristã está necessariamente obrigada? Estamos diante de um perigo que merece ser considerado.

Se o pressuposto da multirreferencialidade da sociedade complexa se mostra como um perigo, por outro lado ele pode ser entendido como um ganho considerável. A multirreferencialidade obriga-nos ao cultivo da humildade e ao gesto de acolhida do diferente. A possibilidade de inúmeras escolhas não deveria ameaçar os cristãos (DGAE 2008-2010, n. 20). Dialogar, acolher, partilhar são verbos verdadeiramente evangélicos e, atualmente, muito reforçados pela pastoral que o papa Francisco nos convida a assumir. A nostalgia de tempos anteriores traz melancolia, impedindo-nos de ver as belezas do tempo presente. Em meio à multiplicidade de ofertas, a fé cristã que a catequese comunica encontra seu espaço, não por privilégios de uma cultura que a favoreça, mas pela força do evangelho na qual ela se sustenta. A fé cristã deve mostrar sua pertinência e sua capacidade de fazer viver. Nesse grande areópago contemporâneo, a fé cristã também tem algo a dizer. No intercâmbio de informações e valores, ela não está sem munição. Ela tem lugar garantido na mesa de debates com outras possibilidades de crer e de orientar a vida. Estar em diálogo humilde com o mundo, sem a pretensão de possuir a verdade, não é prejuízo; ao contrário, é ganho considerável. A fé cristã é desafiada a mostrar sua pertinência, impondo-se não pela força instituída da tradição, mas 
pela força instituinte que a sustenta: a escandalosa cruz de Cristo, ou seja, o mistério pascal.

\section{b) Indivíduo sujeito}

Os indivíduos parceiros da cristandade entraram em extinção. Os agentes sociotransformadores da modernidade arrefeceram suas forças. Um novo indivíduo se delineou na pós-modernidade, aquele cujas energias deslocaram-se de fora de si para dentro de si mesmo, inclusive no campo religioso. Para nós, pósmodernos, o maior desafio não é construir uma terra sem males, coisa que nos parece impossível, pois sentimo-nos um grão de areia no deserto da vida e percebemos que o mundo caminha muito bem sem nós. Nossa maior tarefa se mostra ser nossa própria interioridade. Afirmar nossa subjetividade, confundida pela multiplicidade de ofertas da sociedade multirreferencial, tornou-se tarefa ingente. A afirmação da interioridade é hoje nosso maior desafio e a personalização da fé se apresenta como o único caminho possível para continuarmos a crer.

Diante dessa urgência, a catequese seria omissa se declinasse da obrigação de contribuir com esse processo. A afirmação da identidade não é um luxo, mas uma necessidade dos tempos atuais. Ela pode nos ajudar a tomar gosto pela vida, a saber lidar com os limites da existência, vendo neles não um impedimento para ser feliz mas a possibilidade de se inventar a partir deles. Nesse árduo trabalho de interiorização, o evangelho de Jesus pode ser força que nos capacita a viver plenamente. Quando o acolhemos, aprendemos a administrar as agonias da vida, sem arrancar da nossa existência toda beleza que ela carrega. A fé cristã favorece o bem-viver, pois coloca-nos sob a gratuidade do amor de Deus, ensinando-nos a lidar com as fragilidades e as inconsistências que a vida carrega. Ela pode colaborar - e muito! - com o processo de afirmação da interioridade, pois o evangelho é força que faz viver. 
Quando a interioridade, no entanto, é confundida com individualismo, tudo se complica. Isso poderia comprometer radicalmente a catequese e a proposição da fé cristã. Correríamos o risco de trocar o amor apaixonado pelo outro - que revela de fato quem somos - pelo egoísmo narcísico e individualista. Em nome da afirmação do sujeito, podemos matar o próprio sujeito, cuja vida não se encontra em si mesmo mas no outro que lhe dá diferenciação e configuração própria. Nesse caso, a afirmação do indivíduo seria uma falácia perigosa que nos precipita no abismo do egoísmo. Estaríamos travestindo egoísmo e narcisismo para fazê-los passar por subjetivação, processo que é totalmente avesso a tudo isso. Assim disfarçados, esses dois inimigos podem seduzir os cristãos e minar as forças do compromisso com os irmãos; podem destruir os laços eclesiais e fazer esquecer o compromisso social da fé cristã. Uma ameaça real e perigosa para a fé cristã.

Quando falamos de afirmação da interioridade, somos praticamente obrigados a considerar também o processo de personalização da fé, ou seja, a resposta livre e pessoal que somos convidados a dar a Deus que nos interpela. Para nós cristãos, Deus não é um ser imóvel, uma força cósmica ou um espírito indiferente à vida humana. Deus é pessoa e se dá a conhecer no convívio com os seus. Ele entra em relação conosco, se comunica na primeira pessoa do singular. É o Deus da Escritura que não se envergonha de manifestar seu amor e tomar o partido dos seus, dizendo: "Eu vi a opressão de meu povo e ouvi o seu grito de aflição" (Ex 3,7) ou "És muito precioso para mim; é a ti que eu quero" (IS 42,4). Diante da comunicação de Deus, nossa resposta só pode ser um trabalho pessoal. Ninguém pode responder a Deus por nós, nem mesmo nossa família ou a Igreja. Somente aquele que é interpelado pelo Senhor pode responder ao seu apelo. A relação pessoal que se estabelece com o Deus de Jesus Cristo exige do crente novas configurações, a começar pela própria vida. Somos chamados por Deus a assumir nossa história, a carregar nossa cruz existencial, sem alienações ou escapismos. A autonomia e a maioridade existencial não se coadunam com uma religião alienante. É preciso dar uma resposta a Deus e para isso é preciso estar convencido pessoalmente de seu apelo. Como bem afirmou a CNBB, "as pessoas, ciosas de sua 
liberdade e autonomia, querem se convencer pessoalmente" (DGAE 2011-2015, n. 88). Esse processo de personalização da fé pode ser favorecido por uma catequese mais pneumatológica, pois esta parte do pressuposto da ação do Espírito sobre cada pessoa. A catequese pneumatológica segue a vertente lucana, que afirma a ação do Espírito na vida de todos, sem exceção (cf. At 2,38-39).

A personalização da fé pode, porém, ser confundida com relativismo religioso ou subjetivação unilateral da fé. A subjetivação unilateral se dá por meio da bricolagem de peças religiosas que satisfazem as necessidades do indivíduo. Não importa muito se elas têm coerência interna ou se fazem parte de um conjunto maior. Importa que, ao final, a resultante seja uma fé à imagem e semelhança do crente, moldada segundo suas conveniências. É a religião do oportunismo, cuja característica principal é uma fé cômoda e fácil, justificada pela pretensa afirmação do sujeito. O perigo é a confusão - nem sempre incomum - entre o indivíduo real e o indivíduo afetivo. Este não é o que ele é, mas um escravo de seus gostos ou do que pensa gostar. A subjetivação unilateral da fé não favorece o desabrochar do sujeito, nem afirma sua identidade. Ao contrário, escraviza-o em nome de algumas escolhas e preferências. Não permite que ele se torne sujeito de nada, muito menos de si mesmo, o que é bem diferente da personalização da fé, processo no qual não é a fé que se ajusta à pessoa, mas a pessoa que, ao ouvir o apelo de Deus, deixa-se interpelar por ela.

\section{c) Teologia pneumatoderivada}

A teologia catequética, antes tão centrada em Jesus e na sua encarnação na história, no terceiro paradigma articula-se em torno da ação do Espírito, que revela quem é Jesus e sustenta os discípulos no seu seguimento.

Enquanto a teologia cristoderivada (do paradigma da modernidade) favorece o compromisso com a história especialmente com os pequenos e os socialmente excluídos, a teologia pneumatoderivada parece, aos olhos desavisados, 
favorecer uma fé intimista e subjetiva, sem vínculos sociais ou eclesiais. Essa afirmação faz pensar que o exercício da liberdade é algo individual e não pessoal. Ora, se a liberdade individual é narcísica, a liberdade pessoal contempla a dimensão comunitária, ou seja, a exigência do amor e da fraternidade (POLICARPO, 2009, p. 20). O risco de uma fé confortável e sem compromisso com a história sempre esteve presente na caminhada cristã. Quem conhece um pouco a Carta de Tiago sabe que esse problema é antigo. Contrapondo as tendências espiritualizantes das comunidades ao seu redor, Tiago insiste que fé e obras são duas faces da mesma moeda, não sendo possível pensar a fé cristã a não ser a partir da vida concreta e do compromisso com os sofredores. Não é de hoje que todo cuidado é pouco no esforço de evitar uma fé intimista. Uma fé "para mim”, para satisfazer minhas necessidades pessoais, onde só importam eu e Deus, por mais que fale o nome de Jesus não pode ser dita cristã. A perda do caráter proféticolibertador da fé seria lastimável, pois comprometeria a fé cristã no que ela tem de mais genuína: seu compromisso com a vida, manifestado na cruz de Cristo.

Esse não é, porém, o caso da catequese pneumatológica. A teologia pneumatoderivada do terceiro paradigma não arrefece o compromisso do amor ético, mas leva-o à máxima radicalidade quando põe a centralidade da catequese no mistério pascal. Na cruz, Jesus mostra seu máximo amor, amor que só experimentamos e vivemos pela ação do Espírito. A vida de Jesus entregue na cruz combate qualquer possível enfraquecimento do lado profético da fé. Na cruz, aprendemos que amor é sofrimento, pois exige saída de si e entrega da própria vida pelo outro. O engajamento social da modernidade que perde forças quando o indivíduo é assumido como sujeito de si e não mais como ator social readquire vigor no mistério pascal colocado como centro da catequese. Um outro tipo de engajamento ganha espaço. Ele é certamente mais discreto que o anterior, mas também pode ser dito como mais eficaz. É um compromisso que nasce da relação interpessoal. Com diria Levinas, do rosto do outro que nos interpela, da sua presença que exige resposta. O caminho do militância percorrido pela modernidade não é o único modo de viver a vida cristã. Há sim um caminho que não pode deixar 
de ser percorrido: amar o outro até as últimas consequências como fez Jesus na cruz (Jo 15,12). Mas esse amor tem múltiplas faces. Nós, cristãos pós-modernos, descobrimos que podemos amar o outro e nos comprometer com ele num plano que não está obrigatoriamente dentro dos limites das ideologias sociais. Afinal, a prática tem mostrado que não poucas ideologias humanistas usaram o discurso do amor ao outro, enquanto que suas raízes mais profundas bebiam das águas do amor próprio e da ambição do poder7. É bom deixar claro: o investimento da catequese no mistério pascal não é ameaça ao amor cristão, mas uma boa oportunidade para que ele se efetive como verdadeiro legado de Jesus.

\section{d) Igreja Templo do Espírito}

A imagem Templo do Espírito é mais movente e leve que as demais imagens de Igreja adotadas nos paradigmas anteriores. Ela possui poucos entraves institucionais, como também não carrega o peso das utopias. Sua fluidez afrouxa os laços rígidos de pertença, próprios da Igreja Corpo de Cristo, e sugere uma pertença moralmente menos exigente (bem diferente da Igreja Povo de Deus do segundo paradigma). A Igreja templo do Espírito é entendida como o lugar da experiência do Deus cristão, a ecclesia que ele mesmo reuniu no seu amor. Ela não se fia em imposições contratuais que serviriam de paredes para garantir a pertença do indivíduo. Nela, a pertença se dá pelo desejo, pois é, na partilha e na troca, que os laços de seus participantes são estreitados.

Nesse modelo eclesial, a proposição da fé se dá num ambiente de intercâmbio, de convivialidade e fraternidade. A comunidade eclesial oferece ao mundo o que ela tem de melhor: a preciosidade da fé. Ela comunica uma experiência com o Deus de Jesus Cristo em forma de proposta. Nesse projeto

\footnotetext{
${ }^{7}$ Cf. González Faus, Desafio da pós-modernidade, um comentário ao filme espanhol de Valle-Inclán, Divinas Palavras, que critica as ideologias sociais. Para o teólogo espanhol, o mais significativo do filme está "em seu tema e em seu título, isto é: a colocação em evidência de uma realidade sórdida, cujos únicos conteúdos são avareza secreta, inveja corrosiva e afã de poder destruidor; todos esses conteúdos, porém, estão envolvidos sempre por palavras altissonantes de amor ao oprimido, de defesa da moral ou de citações do evangelho" (GONZÁLEZ FAUS, 1996, p.14-15). Também Geffré, escreveu em 1983: "As pretensões de todos os humanismos foram desmentidas pelo trágico destino do homem desde um quarto de século" (GEFFRÉ, 1983, p. 81).
} 
evangelizador, ela acredita e se empenha. Sabe que a adesão ao evangelho depende da pertinência do que é proposto. Nessa Igreja, observamos a passagem de uma catequese da herança a uma catequese da proposta. O diálogo é sua marca. A comunidade eclesial não se acomoda na fé já adquirida; ao contrário, está sempre se revisando e se reinventando a partir da acolhida da palavra de Deus, pois compreende que ela mesma é a primeira destinatária do que anuncia. A eclesia está convicta que a ação do Espírito burla os limites institucionais (como no relato de Pedro na casa de Cornélio - cf. At 10,23-48) e que a verdadeira justiça não está no cumprimento de leis, mas na capacidade de ultrapassá-las em nome do amor (como José, o justo, que não cumpre o que determina a Lei: denunciar publicamente Maria - cf. Mt 1,18-19). Essa Igreja sabe que Deus sempre surpreende agindo em realidades anteriormente desacreditadas. Atenta a essa ação, sente-se convidada à conversão e à acolhida do dom de Deus. Deixar sua fragilidade à mostra não ameaça a Igreja Templo do Espírito; ao contrário, coloca-a em pé de igualdade com outras realidades favorecendo o diálogo. É muito difícil dialogar com quem nos é superior. Ao superior, cabe a obediência; ao companheiro, a ajuda mútua, a fraternidade, o diálogo. Eis uma vantagem enorme dessa catequese!

A mobilidade e a leveza da imagem Templo do Espírito poderiam, porém, fazer pensar a Igreja como uma realidade abstrata, quase etérea, que dispensaria toda organização institucional, inclusive os diversos ministérios. A comunidade de fé seria uma espécie de anarquia do Espírito, que só não seria mais anárquica porque estaria sob a ação do Espírito. Nesse caso, a eclesia seria entendida como uma comunidade ideal, cujos laços são dados pela afinidade, pelos afetos, sem nenhuma obrigação contratual. Seria mais que uma perda: seria pura ingenuidade idealizar uma Igreja assim.

Façamo-nos entender bem: A Igreja Templo do Espírito não elimina a organização eclesial, nem a definição de ministérios e carismas, afinal o próprio Espírito garante a diversidade dos carismas e as funções no interior da Igreja (cf. 
1Cor 12). Entendemos que não pode haver uma realidade histórica sem organização mínima, sem contratos, interditos, obrigações... A metáfora Templo do Espírito apenas propõe flexibilizar algumas organizações fugindo de posturas obtusas, centrando a organização no maior dom do Espírito: o amor (cf. 1Cor 13). Se a Igreja consegue ser mais leve, flexibilizar seus limites, distribuir melhor as funções eclesiais, apoiar-se mais no amor que a fundamenta que na sua organização, parece salutar. Seria grande ganho para a catequese deixar em suspenso algumas certezas e acolher o novo que o Espírito está nos falando (cf. Ap 2,7).

\section{e) Pedagogia da iniciação}

Diversamente da pedagogia do ensino que prevaleceu no primeiro paradigma ou da pedagogia da aprendizagem que foi o carro-chefe do segundo paradigma catequético, o terceiro paradigma insiste na pedagogia da iniciação como a pedagogia própria da catequese.

Uma das vantagens da pedagogia da iniciação se encontra no resgate do conceito de mistério, especialmente do mistério pascal, tão caro à fé cristã. $\mathrm{O}$ conceito de mistério andou esquecido nos recantos da modernidade, que se sentia esclarecida e lúcida demais para lidar com o que escapava ao seu exame minucioso. Mistério cheirava a ignorância, não-conhecimento, irracionalidade da fé. Mas, entendido como incógnita ou algo sem explicação, o mistério não corresponde ao conceito cristão. Para nós cristãos, mistério é algo que de tão grande nos ultrapassa e, por mais que nele nos enfronhemos, estamos sempre cobertos por sua grandiosidade sem jamais desvendá-la. O mistério insondável do amor de Deus manifestado em Jesus Cristo revela que Deus é sempre maior que nossa compreensão, sempre além de nossas possibilidades, sempre superior aos nossos raciocínios e lógicas. Para a catequese pneumatológica do terceiro paradigma, mais importante que apreender dados da fé, entendidos como resultado de uma dedução lógica ou de uma especulação indutiva da realidade, é ser mergulhado no mistério pascal que transcende toda lógica da realidade, pois a fé cristã se situa no universo 
da gratuidade absoluta. A pedagogia da iniciação resgata, pois, o conceito básico da fé cristã, o mistério pascal, e dá a ele centralidade.

Outro risco do terceiro paradigma, resultante da pedagogia da iniciação, é a eliminação do caráter cognitivo da fé, que faria a catequese cair no sentimentalismo. Sabemos, no entanto, que a pedagogia da iniciação contempla o homem integral, inclusive sua necessidade de dar as razões da fé. Priorizar na catequese a relação interpessoal com o Deus de Jesus Cristo que se autocomunica, e não a transmissão de uma doutrina ou mensagem, não elimina a vertente do saber. A fé cristã não está desobrigada de buscar suas razões. Apesar de a razão não ser a fonte primeira do mistério, ela é constitutiva do ser humano que busca e experimenta Deus. Dar as razões da fé não é coisa dispensável para o cristão. A estruturação intelectual da fé não é um acessório; ela representa uma condição essencial da vida de fé, e a pedagogia da iniciação não a exclui, ao contrário, a afirma, só que de forma mistagógica. Como afirmaram os bispos da América Latina e Caribe: "O encontro com Cristo, Palavra feita carne, potencializa o dinamismo da razão que procura o significado da realidade e se abre para o Mistério" (DAp, n. 280c). O terceiro paradigma não subestima a mediação racional que é necessária à maturação autêntica da fé (VILLEPELET, 2009a, p. 445). Nele, quem tem o protagonismo é Deus que se comunica e não a mensagem por ele comunicada, apesar de esta ser o resultado natural dessa comunicação (VILLEPELET, 2009a, p. 136).

\section{Conclusão}

Conhecemos o paradigma catequético da pós-modernidade, cuja catequese é bem mais pneumatológica que as anteriores. Para mostrar o terceiro paradigma que vem ganhando corpo na contemporaneidade, falamos brevemente dos outros dois paradigmas catequéticos e conhecemos os parâmetros dominantes que os caracterizam. Certamente, na prática, os paradigmas não são gavetas estanques como pode parecer aqui. Há um intercâmbio, uma bricolagem de partes de cada 
um deles, formando um mosaico catequético bem original. É bem próprio da pósmodernidade fazer bricolagens. No entanto, na hora de apresentar os paradigmas, é importante fazer distinções bem claras, que são apenas pedagógicas e não reais. Nas comunidades eclesiais, porém, tudo se mistura e os catequistas transitam de um paradigma a outro sem receio ou culpa.

Apesar de reconhecer a validade dos paradigmas anteriores e das catequeses teoderivada e cristoderivada, fizemos questão de tomar partido do terceiro paradigma, ou seja, de uma catequese pneumatoderivada. Não retiramos o mérito de nenhum dos modelos catequéticos com os quais já trabalhamos ou que ainda vigoram em nossas paróquias. Apenas queremos mostrar que, apesar de toda contribuição dessas catequeses, a mudança epocal sinaliza para uma catequese mais pneumatológica.

Sabemos também dos perigos e desvios aos quais essa catequese está sujeita. Fizemos o levantamento de alguns deles, mostrando como corrigi-los. Porém, nenhum dos riscos teológico-pastorais acima apresentados nos parecem consideráveis diante dos ganhos que tal catequese possibilita. Só podemos ver com bons olhos uma catequese que se abre à ação do Espírito e mergulha o catequizando no mistério pascal. Só podemos entender como ganho se a catequese cumpre essa tarefa, essa missão.

\section{REFERÊNCIAS}

AMADO, Joel Portella. Amar como Jesus amou: vida segundo o Espírito. In: RUBIO, Alfonso García; AMADO, Joel Portella (Orgs.). Espiritualidade em tempos de mudança: contribuições teológico-pastorais. São Paulo: Vozes, 2009. p. 125-138.

CARMO, Solange Maria. Catequese no mundo atual: crises, desfios e um novo paradigma para a catequese. São Paulo: Paulus, 2016.

CODINA, Victor. Prioridade teológico-pastoral da pneumatologia hoje: "o Espírito precede a vinda de Cristo” (São Basílio). Perspectiva Teológica, Belo Horizonte, v. 44, n. 122, p. 69-86, 2012. 
CONFERENCIA NACIONAL DOS BISPOS DO BRASIL. Diretrizes Gerais da Ação Evangelizadora da Igreja no Brasil 2011-2015. São Paulo: Paulinas, 2011. (Documento 94).

CONFERÊNCIA NACIONAL DOS BISPOS DO BRASIL. Diretrizes Gerais da Ação Evangelizadora da Igreja no Brasil 2008-2010. São Paulo: Paulinas, 2008. (Documento 87).

CONGREGAÇÂO PARA O CLERO. Diretório Geral para a Catequese. São Paulo: Paulinas, 2003.

CONSELHO EPISCOPAL LATINO-AMERICANO. Documento de Aparecida: texto conclusivo da V Conferência Geral do Episcopado Latino-Americano e do Caribe. São Paulo: Paulinas, 2009.

GEFFRÉ, Claude. O destino da fé cristã num mundo de indiferença. Concilium, Petrópolis, n. 185, p. 89, 1983.

GONZÁLEZ FAUS, José Ignacio. Desafio da pós-modernidade. São Paulo: Paulinas, 1996.

GONZÁLEZ FAUS, José Ignacio. La Iglesia católica-romana no es la verdadera Iglesia de Cristo. Revista Latino-americana de Teologia, El Salvador, n. 83, 2011.

KONINGS, Johan. Ser Cristão: fé e prática. Petrópolis: Vozes, 2007.

LACROIX, Roland; VILLEPELET, Denis. Une question à la foi: la catéchèse, écho d'une parole de vie. Paris: L'atelier, 2008.

MARTIN VELASCO, Juan. La experiencia cristiana de Dios. Madrid: Editorial Trotta, 1995 .

POLICARPO, José da Cruz. La situation et les défis de la mission aujourd'hui en Europe. In. BIEMMI, Enzo; FOSSION, André (orgs.). La Conversion missionaire de la catéchèse: proposition de la foi et première annonce. Bruxelles: Lumen Vitae, 2009. p. 15-23.

VILLEPELET, Denis. Catéchèse d'adultes et maturation de la foi. Lumen Vitae, Bruxelas, v. 63 , n. 4, p. 387-388, 2008a.

VILLEPELET, Denis. Initiation et pédagogie. Catéchèse, Paris, n. 161, p. 16-23, 2000.

VILLEPELET, Denis. Initiation et philosophie de l'éducation. Croissance de l'Église, Paris, v. 108, n. 93, p. 29-34, 1993.

VILLEPELET, Denis. L'avenir de la catéchèse. Paris: L’atelier/Ouvrières, 2003.

VILLEPELET, Denis. La centralité du présent. Cahiers de l'Atelier, Paris, n. 523, p. 5664, 2009a. 
VILLEPELET, Denis. La liberté comme obligation. Cathéchèse, Paris, n. 158, p. 35-43, 2000.

VILLEPELET, Denis. Les défis de la transmission dans un monde complexe. Paris: Desclée de Brouwer, 2009b.

VILLEPELET, Denis. Mutations chez les catholiques. Responsables, Paris, n. 363, p. 6-9, 2005.

VILLEPELET, Denis. O futuro da Catequese. São Paulo: Paulinas, 2003.

VILLEPELET, Denis. Propos sur les paradigmes catéchètiques. Catéchése, Paris, n. 165, p. 21-44, 2001. 